\title{
Green Technology: Production of Biogas from Solid Wastage of Dhaka City
}

\author{
Md. Salehin Ferdous ${ }^{1}$, Sabrina Tasnim ${ }^{2}$, Arifuzzaman $^{3}$, Md. Rumman Rafi ${ }^{4}$ \\ ${ }^{1}$ Assistant Professor, Department of Electrical \& Electronics Engineering, Fareast International University, \\ House: 51, Road: 11, Block: C, Dhaka, Bangladesh-1213 \\ ${ }^{2}$ Lecturer, Department of Computer Science \& Engineering, Sonargaon University, \\ Campuse-1:147/I Green Road, Tejgaon, Dhaka, Bangladesh-1215 \\ ${ }^{3}$ Lecturer, Department of Mathematics, Fareast International University, \\ House: 51, Road: 11, Block: C, Dhaka, Bangladesh-1213 \\ ${ }^{4}$ Lecturer, Department of Electrical \& Electronics Engineering, Fareast International University, \\ House: 51, Road: 11, Block: C, Dhaka, Bangladesh-1213
}

\begin{abstract}
Bangladesh is an over populated country. Here, poor people are deprived from all modern facilities in which electricity is most important factor. Cost of the electricity is getting higher every day. So rethink about renewable energy to generate electricity is essential. Tons of wastage materials are produced daily basis in Dhak city. If we can use these wastage materials to produce electricity, then it will be most cost effective, more beneficial and environment friendly. The project has been completed to create biogas which will be more cost effective, eco-friendly, cut down landfill, generate a high quality renewable fuel, and reduce carbon dioxide $\left(\mathrm{CO}_{2}\right)$ and methane $\left(\mathrm{CH}_{4}\right)$ emissions. A biogas reactor has been build up for producing biogas in electrical circuit lab of Fareast International University. We collect wastes from our nearest dustbin, poultry and dairy farms along with residence. We made a mini biogas plant by three plastic bottles and other necessary materials. The operating principle of the plant is similar with anaerobic digesting system to produce biogas. The produced gas should be purified by deducting carbon dioxide $\left(\mathrm{CO}_{2}\right)$ and other gases. The biogas can be used for producing electricity and also for numerous purposes.
\end{abstract}

Keywords: Biogas, City waste, Renewable energy, Methane

\section{Introduction}

Biogas normally alludes to a blend of various gasses created by the breakdown of natural organic materials without oxygen. Biogas can be delivered from crude materials, for example, farming waste, compost, metropolitan waste, plant material, sewage, green waste or nourishment squander. Biogas is a sustainable power source.

However biogas is particular from others due to its use, control and accumulation effortlessness. It has no any topographical impediments or it require propelled innovation for creating vitality. City squander contains around $70 \%$ of kitchen squander. Huge measure of this waste created every day. Kitchen squander is natural material having high calorific esteem and nutritive incentive to micro organisms that is the reason effectiveness of methane creation can be expanded. Accordingly, the span of reactor and cost of biogas creation is decreased. In Dhaka city, kitchen squander arrange in landfill which causes general wellbeing dangers and sicknesses like intestinal sickness, cholera, typhoid and others. Uncontrolled evacuation of squanders, a few unfortunate circumstances is made.

Utilizing low calorific sources like dairy cattle compost, refinery emanating, civil strong waste (MSW) or sewerage, in biogas plant, making methane age exceptionally wasteful. We can make this framework amazingly productive by utilizing kitchen or sustenance squanders (wastage). Although all city squanders contain comparable sort of natural substances, however squanders ought to be diverse for better places.

\section{Related Works}

In 2003, Dr. Anand Karve [1] built up a smaller biogas framework that utilize starchy or sugary feedstock material e.g. squander grain flour, spoilt grain, over ripe or distorted natural product, non palatable seeds, leafy foods, green leaves, kitchen squander, remaining sustenance and so forth and the examination demonstrates this new framework is 800 times more effective than traditional biogas plants. In smaller biogas framework, $2 \mathrm{~kg}$ of feedstock delivers roughly $500 \mathrm{~g}$ of methane; the response is finished inside 24 hours and the regular framework, $40 \mathrm{~kg}$ of feedstock create a similar measure of methane, and required around 40 days for finishing the response. In this manner, from the perspective of change of feedstock into methane, the framework created by Dr. Anand Karve [2,3] is more productive as the traditional framework. We have attempted to plan and examination on biogas delivering from squanders of Dhaka city utilizing the traditional technique. The best possible transfer of our city waste will be done in Ecoaccommodating and cost successfully.

\section{Biogas}

Biogas is produced by bacteria through the bio-degradation of organic material under anaerobic conditions. Natural

\section{Volume 8 Issue 8, August 2019}




\section{International Journal of Science and Research (IJSR) \\ ISSN: 2319-7064}

ResearchGate Impact Factor (2018): 0.28 | SJIF (2018): 7.426

generation of biogas is an important part of bio-geochemical carbon cycle. It can be used both in rural and urban area.

Many factors affecting the fermentation process of organic substances under anaerobic condition are:

1)The quantity and nature of organic matter.

2)The temperature.

3)Acidity and alkanity (PH value) of substrate.

4)The flow and dilution of material.

\section{a) Principles of biogas production}

Natural substances exist in wide assortment from living creatures to dead life forms. Natural issues are made out of carbon (C), joined with components, for example, Hydrogen $(\mathrm{H})$, Oxygen $(\mathrm{O})$, Nitrogen $(\mathrm{N})$, Sulfur $(\mathrm{S})$ to frame assortment of natural mixes, for example, sugars, proteins and lipids. In nature MOs (microorganisms), through absorption process breaks the unpredictable carbon into littler substances.

There are two types of digestion process:

1)Aerobic digestion

2) Anaerobic digestion

The digestion process taking place in the presence of oxygen $\left(\mathrm{O}_{2}\right)$ is called aerobic digestion and that of taking place without oxygen is called anaerobic digestion.

\subsection{Experimental Details}

The work conducts at our lab in small scale with plastic bottles.

\section{a) Source of kitchen waste}

The used waste is collected from our residence i.e. cooked rice and vegetables which crushed by grinder; slurry prepared with water mixing.

\section{b) Lab scale}

This experiment made with three 5.0 litters' bottles. Here different types of concentration \& combination of wastes are used. Different parameters of input are measured e.g. total solid, volatile solid, volatile fatty acid, $\mathrm{pH}$, temperature, nitrogen, carbon, and phosphorous.

\section{c) Precautions while collecting sample kitchen waste}

1) A separate container for kitchen waste e.g. egg shells, peels and chicken mutton bones whose are crushed separately by grinder.

2) Another container collects the wet waste, stale cooked food, waste milk products. The vegetables refuse like peels, rotten potatoes, coriander leaves collected in bags.

3) A separate container for hen meaner collects from near market.

4) Cow dugs collect near a dairy farm.

\section{d) Installations}

By avoiding the choking of the plant is important aspect in smoother running of plant. This occurs due to thick biological waste that not reaches to the microorganisms to digest. The easy answer to this problem is to convert solid wastes into liquid slurry. Mixer can be used to convert solid into slurry.

\section{e) Description of the plant}

This experiment help to understand that biogas generation is possible from kitchen waste. We installed three different digesters where three different wastes used. Different mixtures produce different amount of gas. We used three types of mixture as follows

1) Only kitchen waste

2) Kitchen waste and cow dung

3) Kitchen waste and hen manure

\section{f) Plan of digester}

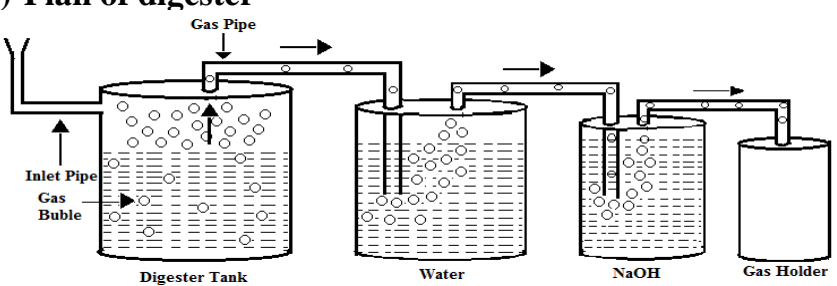

Figure 1:Biogas plant

\section{g) Necessary Apparatus}

Digester tank, plastic pipe, $\mathrm{NaOH}$, water, bottle, gum, plastic pipe.

\section{h) Process}

First take a 5 litter water bottle for digester tank. A PVC (inlet) pipe is adjusted with the digester tank as fig 1 . Digester tank, water bottle, $\mathrm{NaOH}$ bottle and gas holder are inter linked with similar plastic pipe.

\section{i) Working Process}

Biogas technology has mainly concentrated on "wet fermentation" of agricultural waste. So biogas produces mainly by fermentation process which converts waste into Methane $\left(\mathrm{CH}_{4}\right)$ gas. The methane gas contains some water vapors and extra gases which send through the plastic pipe into water bottle for absorbing water vapors. Again, the gas is sent through the plastic pipe into $\mathrm{NaOH}$ bottle for absorbing $\mathrm{CO}_{2}$ gas. As a result fresh Methane gas is sent into the gas holder. A valve is provided for using the gas. Factors affecting biogas yield [10] are:

1)Carbon/Nitrogen $(\mathrm{C} / \mathrm{N})$ ratio

2)Temperature

3) $\mathrm{pH}$ value

4)Loading rate

These following steps are followed for biogas production at daily basis:

1) Volume of gas produced was recorded daily.

2) The temperature of the digester content was taken twice daily.

3) The $\mathrm{pH}$ of the digester content was taken weekly.

4) Weekly collection of samples for the isolation and assessment of the microbial population causing the bioconversion at different stages.

5) Measurement of the retention time i.e. time between the commencement of gas production and termination of the experiment.

6) Measurement of the amount of gas produced at the end of the experiment.

7) Analysis of the gas to separate it to its different components. 


\section{International Journal of Science and Research (IJSR) \\ ISSN: 2319-7064}

ResearchGate Impact Factor (2018): 0.28 | SJIF (2018): 7.426

8) Physico-chemical analysis of the digester content after the termination of the experiment

9) Concentration of the digested substrate to form biofertilizer.

\subsection{Results with Discussions}

This experiment accomplished with $2 \mathrm{~kg}$ kitchen waste e.g. vegetable, food, meat etc. are crushed with blender; then mixed with 2 liter water to make slurry in a biogas digester. After 4 or 5 days, it produced gas bubble i.e. biogas. The production of biogas depends on the following factors

1) Temperature $\left(35-40^{\circ} \mathrm{C}\right.$ for bacteria)

2) $\mathrm{pH}$ (Suitable Range 6.25-7.20)

3) $\mathrm{C} / \mathrm{N}$ ratio ( Carbon and Nitrogen ratio $25: 1$ to $30: 1$ )

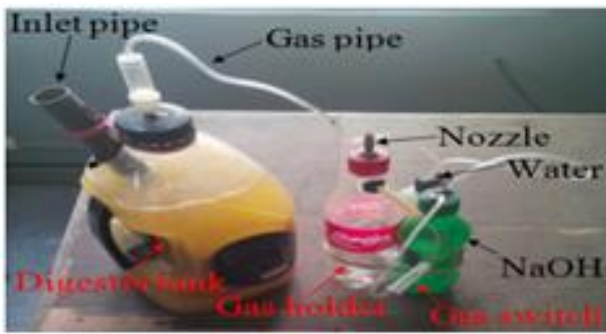

Figure 2: Biogas digester

Observation:

1)Water level of inlet pipe increased

2)Smell like as rotten egg

Results: Gas produced and burnt with blue flame.

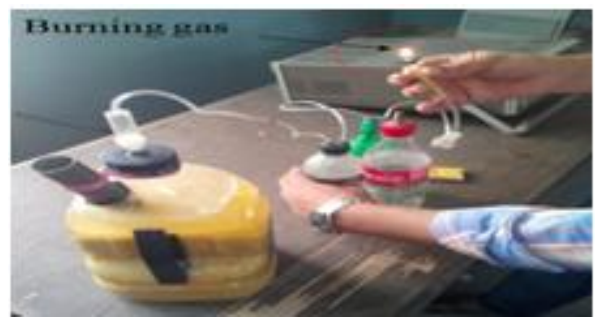

Figure 3: Biogas burn

\section{B. Experiment 2}

This experiment done by $2.5 \mathrm{~kg}$ cow dung and kitchen waste and 2 liter water is mixed in biogas digester. The kitchen waste must be crushed with a blender machine. After 3 or 4 days gas produced. For biogas production, similar factors maintained as experiment 1 .

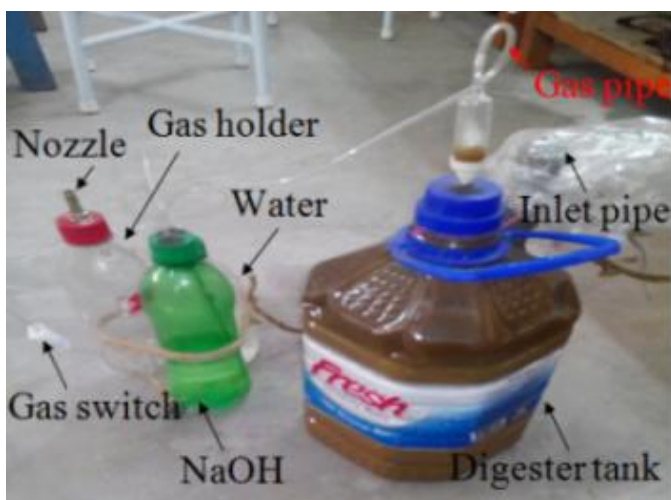

Figure 3: Biogas digester

Observation:

1) Water level of inlet pipe is increased.

2) Smell like as rotten egg.

\section{$\underline{\text { Results }}$}

Gas produced and burnt with blue flame.

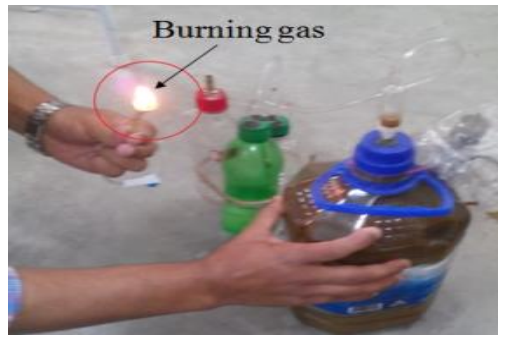

Figure 5: Biogas burn

\section{Experiment 3}

This experiment done $2.5 \mathrm{~kg}$ hen meaner, cow dung, kitchen waste and 2.5 liter water is properly mixed in a digester. After 4 or 5 days gas produced. For biogas production, similar factors maintained as experiment 1 .

Observation:

1) Water level of inlet pipe is increased

2) Smell like as rotten egg

City waste is increasing day by day not only in Dhaka city but also in the world. Though the waste is fall down in dustbin it pollute environment seriously. If the waste may be used to produce biogas it gives two facilities, one is safe the environment from pollution and second is achieve biogas which is the easiest form of renewable energy.

\section{Discussion of three methods:}

These three experiments have not produced same amount of gas that is given bellow-

1) Experiment No.-1: Start producing biogas after 4 or 5 days and capable to burn after 15 days.

2) Experiment No.-2: Start producing biogas after 3 or 4 days and capable to burn after 12 days and the amount of produced gas more than that of the first experiment.

3) Experiment No.-3: Start producing biogas after 2 or 3 days and the amount of produced gas more than that of the above two experiments.

Finally we decided that the experiment No.-3 is more effective for biogas production and produce more amount of gas among them and less time required. 


\section{International Journal of Science and Research (IJSR) \\ ISSN: 2319-7064}

ResearchGate Impact Factor (2018): 0.28 | SJIF (2018): 7.426

\subsection{Use of Our Biogas Plant}

Biogas can be used in a specially designed burner for cooking purpose. A biogas plant of 2 cubic meters capacity is sufficient for providing cooking fuel needs of a family of about five persons. Biogas is used in silk mantle lamps for lighting purpose. The requirement of gas for powering a 100 candle lamp $(60 \mathrm{~W})$ is 0.13 cubic meter per hour.

Biogas can be used to operate a dual fuel engine to replace up to $80 \%$ of diesel-oil. Diesel engines have been modified to run 100 per cent on biogas. Petrol and CNG engines can also be modified easily to use biogas.

After removal of $\mathrm{CO}_{2}, \mathrm{H}_{2} \mathrm{~S}$ and water vapor, biogas can be converted to natural gas quality for use in vehicles.

\section{Conclusion}

The measure of waste is rising bit by bit with disturbing rate and $70 \%$ of those are sustenance and vegetables which are may turn into a sustainable power source. The best possible transfer of our city waste will be done in eco-accommodating and financially savvy way. While figuring the cost viability of waste transfer we need to think more than monitory prospects. The dumping of sustenance in spots and making the spots unhygienic can be taken great care of. It adds to the estimation of such biogas plants. Utilizing the common procedures like small scale creature's kitchen squander and biodegradable waste viz. paper, mash can be used. Anaerobic absorption is controlled natural debasement process which permits productive catching and usage of biogas (approx. 60\% methane and $40 \%$ carbon dioxide) for vitality age. Anaerobic processing of nourishment squander is achievable yet unique sorts, synthesis of sustenance squander brings about changing degrees of methane yields, and in this way the impacts of blending different sorts of nourishment squander and their extents ought to be resolved on case by case premise.

\section{References}

[1] http://en.wikipedia.org/wiki/Waste_management_in_Bangl adesh\#cite_note-1

[2] A Discussion on Factors Affecting Biogas Production and Field Investigation of a Novel Duplex Digester, http://web.iitd.ac.in adewan/Dewan_2005_SESI_Duplex_Digester.pdf

[3] Report No. ETSU B 1118, 1986, Research into the development of Prototype Units for the Production of Biogas Methane from Farm Wastes and Energy Crops, Department of Microbiology, University College, Cardiff.

[4] Wise, D.L., 1987, Global Bioconversions, CRC Press, Florida, Vol. IV, pp. 178-189.

[5] Mahanta, P., Dewan, A., Saha, U.K. and Kalita, P., 2004, Influence of Temperature and Total Solid Concentration on the Gas Production Rate of Biogas Digester, Journal of Energy in Southern Africa, Vol. 15 (4), pp. 112-117.

[6] Karve .A.D. (2007), Compact biogas plant, a low cost digester for biogas from waste starch, http://www.artiindia.org.

[7] REN21,wikipedia, September 2015, http://en.wikipedia.org/ wiki/ REN21
[8] Renewable 2014 Global Status Report, http://www.ren21.net/ Portals/ 0/documents/Resources/GSR/2014/GSR2014_full\%20repo rt_low\%20res.pdf

[9] Waste management in Bangladesh, April, 2015, http://en.wikipedia .org/wiki/Waste_management_in_Bangladesh\#cite_note-2

[10] Waste management in Bangladesh, http://en.wikipedia.org/wiki/ Waste_management_in_Bangladesh\#cite_note-5

[11] Waste management in Bangladesh, http://en.wikipedia.org/wiki/ Waste_management_in_Bangladesh\#cite_note-7

[12] Biogas,http://www.biogas-renewable-energy.info/biogas_ composition.html

[13] Theses Report, http://ethesis.nitrkl.ac.in/2547/1/THESIS FINAL_REPORT.pdf, Chapter 7

[14] Biogas Cleaning http://www.ietl.in/index.php/biogas-cleaningdesulphurization-system-H2S-scrubber,

\section{Author Profile}

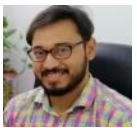

Md. Salehin Ferdous Kader is working as an assistant professor and Head of Department in EEE at Fareast International University (FIU). Currently he is doing his Ph.D research on Optical Fiber Communication from Islamic University of Technology (IUT). He completed his B.Sc and M.Sc from same university. His research interest is on AdHoc networking, Renewable Energy, IOT, Bio Medical Engineering.

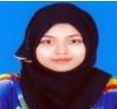

Sabrina Tasnim as a Lecturer in the Department of Computer Science \& Engineering at Sonargaon University, Dhaka, Bangladesh. Sabrina earned her B.Sc degree (CSE) from Begum Rokeya University, Rangpur and M.Sc degree (CSE) from Jahangirnagar University, Dhaka, Bangladesh. She worked as a Lecturer at Fareast International University, Dhaka, Bangladesh. Sabrina has published research articles in reputed International and National journals.

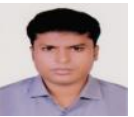

Arifuzzaman as a Lecturer in the Department of Mathematics at Fareast International University, Dhaka, Bangladesh. Arifuzzaman obtained his B.Sc and M.Sc in mathematics from Jagannath University, Dhaka, Bangladesh. Arifuzzaman has published research articles in reputed journals.

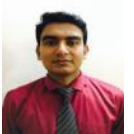

Md. Rumman Rafi as a Lecturer in the department of Electrical and Electronic Engineering at Fareast International University, Dhaka, Bangladesh. Rumman obtained his B.Sc in EEE from Islamic University of Technology (IUT), Dhaka, Bangladesh. Rumman has published research articles in reputed journals. 